\title{
'FUELLED BY DREAMS AND POWERED BY IMAGINATION': CONSIDERING DIGITAL TECHNOLOGIES THROUGH THE LENS OF A THEOLOGY OF PLAY
}

The Simpsons, in an episode of the eponymous cartoon series, make a trip to Springfield's Mapple Store. Homer is entranced by the array of digital devices and a helpful sales assistant tells him that all these are "fuelled by dreams and powered by imagination." The writers capture vividly the social construction of digital technologies. Our societies are dependent upon digital technologies. These technologies shape our options and designdecisions are made that reflect our changing attitudes. In a nutshell, we place a lot of faith in digital technologies for the lifestyles to which we have become accustomed and to which we aspire. Yet, at the very same time, digital innovations open wider horizons and alter our expectations. Digital technologies are not mere devices we use or infrastructures upon which we rely. Digital technologies are a cultural phenomenon conveying narratives in which are embedded assumptions, values and norms. We have faith in digital technologies that they will deliver the goods promised. Crucially, we allow the digital world scope to alter our horizons. Yet, as citizens, consumers, and users we are not subsumed by the digital world - we are both complicit and resistant. We are dutiful 'clickers' who follow the instructions but we are subversive appropriators who find our own uses for particular technologies. Like Homer, we are dazzled by the shiny gadgets waved in our faces by marketers - but we exercise political and commercial power that shapes what is offered to us.

This paper aims to interpret digital technologies through the lens of a theology of play because the distinctions between work, information, and entertainment are now blurred. This new cultural feature requires that we add to existing richly textured theological critiques in order that we can be alert to, and contribute towards, robust engagement with powerful systems that shape contemporary society.

We will first outline Catholic teaching on social communications, giving particular attention to recent Papal messages for the annual World Communications Day, before placing it in a wider theological context. We will argue that, whilst consideration of the entertainment industry is not absent from theological discussions, the propensity for entertainment and leisure to become a paradigm for social communications is an opportunity for a turn to other theological themes; namely play. Thus, our focus is not upon any digital device or software that is explicitly designed and marketed for play. Rather, a theology of play enables us to engage with the prevalence of entertainment as a mode of living in, with and through digital technologies.

\section{BLURRED BOUNDARIES}

\section{Infotainment}

Interweaving informative material and entertainment content in print, broadcast and internet media is an extensive contemporary practice although, as David Gordon observes, an approach that has its origins in the sensationalist reporting of scandals and crimes in the $19^{\text {th }}$ century. ${ }^{2}$ The neologism, "infotainment" was coined in 1980 and can be difficult to avoid given the pressure of media producers to secure ratings or, in the online environment, hits or

\footnotetext{
${ }^{1}$ Marc Wilmore (writer), Steven Dean Moore (director), 'Mypods and broomsticks', The Simpsons Season 20, Episode 7; Production Code KABF20. First aired: November 30, 2008.

${ }^{2}$ A. David Gordon and John Michael Kitross, Controversies in Media Ethics - 2nd Edition (New York: Longman, 1999), 228.
} 
likes that, in turn, feed advertisers' coffers. In stark terms, when it comes to editing news, there is the dictum, "if it bleeds, it leads." ${ }^{3}$ It is important, however, to recognize that straightforward and rigid distinctions between news and entertainment are elusive. As Michael Delli Carpini and Bruce Williams argue, traditional categories "are social constructions that tell us more about the distribution of political power than about the political relevance of different genres." ${ }^{4}$

Infotainment may, on the one hand, attract larger audiences to information because it has been packaged in innovative and interesting ways. So too a focus on human interest, jeopardy and emotion in particular, may present stories better than might a significantly rational, analytical approach. There is an argument that reaching people through infotainment is necessary in order to develop an informed democracy. ${ }^{5}$ On the other hand, it is feared that people, short on time and inclination, will imbibe only the over-simplified, trivialized and titillating programs or websites. $^{6}$

It may be that viewing infotainment makes a person objectively more informed but we should not discount the extent to which viewers might simply feel better informed. ${ }^{7}$ The public are, of course, not blank slates but people with often intensely emotional perspectives. Cynicism towards, for example, politicians and politics in general may be generated by exposure to infotainment that focuses on the scandals and non-political traits of politicians (the privatization of news). When the human interest angle is dominant in content (the personalization of news), there may be a reduction in cynicism. ${ }^{8}$

\section{Weisure}

US sociologist Dalton Conley coined the term "weisure" to describe that combination of work and leisure that features significantly in the lives of much of the professional class. Leisure, he argues, is instrumentalized and not only in parents' own lives but in the opportunities they afford and the expectations they instil within their children:

we certainly keep our kids busy - nearly as busy as we are ourselves. Every second is an opportunity for investment in their human and cultural capital - that is, in their cognitive and non cognitive skill sets. Our kids are not playing; rather, they are learning to socialise with their peers. They are not mashing clay; they are developing their manipulative dexterity in a three-dimensional medium. They are not kicking the ball around; no, they are physically challenging their fine and gross motor skill. ${ }^{9}$

Weisure is more than being able to work anywhere at any time so that childcare might be combined with employment responsibilities (seen, for example, in the father pushing his daughter on a swing whilst he is making a business call on his cell). As Eran Fisher contends, "it also entails the fusion of creativity, joy, and personal expression into work and, in turn, the dealienation of work." ${ }^{10}$ Whilst work is intruding into family life, work is also

\footnotetext{
${ }^{3}$ Cynthia Carter and Stuart Allan, "If It Bleeds, It Leads': Ethical Questions About Popular Journalism,' in David Berry (ed.), Ethics and Media Culture: Practices and Representations (Burlington, MA and Abingdon: Focal Press, 2013 [2000]).

${ }^{4}$ Michael X. Delli Carpini and Bruce A. Williams, 'Let Us Infotain You: Politics in the New Media,' in W. Lance Bennett and Robert M. Entman (eds), Mediated Politics: Communication in the Future of Democracy (Cambridge: Cambridge University Press, 2001), 163.

${ }^{5}$ Gordon and Kitross, Controversies, 230.

${ }^{6}$ Carol Reuss makes this point in her contribution to Gordon and Kitross's text, Controversies, 231.

${ }^{7}$ Tamara Mattheiß and others, 'Political Learning through Entertainment - Only an Illusion? How Motivations for Watching TV Political Talk Shows Influence Viewers' Experiences,' Journal of Media Psychology: Theories, Methods, and Applications 25: 4 (2013).

${ }^{8}$ Nael Jebril, Erik Albæk, and Claes H. de Vreese, 'Infotainment, Cynicism and Democracy: The Effects of Privatization Vs Personalization in the News,' European Journal of Communication 28: 2 (2013).

${ }^{9}$ Dalton Conley, Elsewhere, USA (New York: Vintage Books, 2010), 30-31.

${ }^{10}$ Eran Fisher, Media and New Capitalism in the Digital Age: The Spirit of Networks (New York: Palgrave Macmillan, 2010), 84.
} 
being reconceived as no longer "the negation of leisure and freedom." ${ }^{\text {"11 }}$ These changes have become possible only because of digital technologies. Although it might be tempting to think of online and offline as two separate domains between which we flee, retreat or navigate efficiently, it is perhaps more accurate to resist such "digital dualism" and deal, instead, with their interpenetration. ${ }^{12}$

Our attempts to keep personal and business email inboxes discrete can feel like a losing battle. Distinguishing which of our Facebook friends are (still) professional contacts can be tricky, given that many of our social events might include speculative professional conversations. As journalist and commentator Gaby Hinsliff has pondered, "Is surfing Twitter work, if you're ostensibly checking for breaking news - or play, given you inevitably become sucked into conversation?",13

The combination of infotainment and weisure diffuses the boundaries that once could be more easily drawn around learning, play and work. The effect is compounded when we use the same iPad for work, play, social communication and domestic activities. It may also be the case that we use that iPad at work, at play and at home.

\section{Professional Tools and Toys}

The distinction between professional device and toy is also blurred. Careful employers restrict the software that a user can add to a portable computer used for work - that the company nevertheless expects will be taken home for evening and week-end working. Similarly, employees are cautious, knowing their browsing can be subject to real-time and post hoc surveillance, about the range of uses to which they put their office laptop.

Bond and obligation are important dimensions of toys. Where toys operate as an exchange we anticipate a return. Perhaps we give a toy with the expectation that we will receive love from its recipient. We may give toys to children in anticipation of good behaviour. To a considerable extent Christmas has become the "festival of toys" and we "judge what people think is terribly important by where they put their money." 14 It should come as no surprise then that the cultural cache of new models of computer produced by the coolest company can be drawn upon to reward favoured employees (or withhold such reward). Who wants to be the sole Windows Vista user at a meeting where others are flaunting their MacBook Airs (and possibly competing amongst themselves as to specifications)?

Toys have a cultural role in preparing children for being solitary in adulthood because it is in being on our own that we can think issues through. Perhaps less admirably, it is a "solitary striving for achievement" that characterises much of contemporary life. ${ }^{15}$ Despite the ubiquity of online social networking and some emphasis on team work within corporations, the icon of contemporary business life is the diligent professional sitting alone in an airport lounge cocooned in her digital world with an iPad in her hand, striving to at least consolidate if not advance her position in the market and in her own company.

Toys can also serve as transitional objects, providing consolation as substitute friends. ${ }^{16}$ Transitioning from intense relationships with parents is a disconcerting experience so a child may find that clasping a toy stands-in for the retreat to the safety of a parent's arms that is temporarily unavailable. Anxiety in adults over the loss of cell or wi-fi connectivity for

\footnotetext{
${ }^{11}$ Fisher, Media and New Capitalism in the Digital Age: The Spirit of Networks, 87.

12 Nathan Jurgenson, "The IRL Fetish", The New Inquiry http://thenewinquiry.com/essays/the-irlfetish/ (accessed 2 May 2014).

${ }^{13}$ Gaby Hinsliff, "The Merge: How Our Work-Life Balance Is Changing", The Guardian http://www.theguardian.com/money/2013/jan/01/merge-work-life-balance (accessed May 6, 2014).

${ }^{14}$ Brian Sutton-Smith, Toys as Culture (New York: Gardner Press, 1986), 21.

${ }^{15}$ Sutton-Smith, Toys, 24.

${ }^{16}$ D.W. Winnicott, Playing and Reality (London: Tavistock Publications, 1971).
} 
even a short period is prevalent and may include, it is argued, some elements of grief reaction. ${ }^{17}$

It is not that women do not derive pleasures from toys - but the gendered trope of "boys and their toys" is not insignificant. The stereotypical computer nerd or geek is a young(ish) man who derives pleasure in creating (or in the case of high-level technology, adapting) devices that have fallen into his hands. In designing software men may experience exhilaration at what technology can do.$^{18}$ They may vicariously take on some of the properties of the artefacts although software designers are usually involved in only a small section of what is otherwise an invisible larger project. Hands-on tinkering and the "rituals of tinkering" (such as sharing stories at coffee breaks) contribute to the gender positioning of the acquisition of knowledge, skills and expertise. ${ }^{19}$ The comfort of total absorption and familiarity with a gadget forms part of a man's emotional engagement in which he can see the machine as "his [sic] creation, his child, his servant, his master, his glory and his nemesis." 20 Sherry Turkle refers to the "intimate machine" as an object experienced as alive. ${ }^{21}$ Software professionals have been found to address their computer in frustration, although not quite in the same way as those building robots do. ${ }^{22}$

The blurring of boundaries described by infotainment, weisure and what we might call professional toys are significant social experiences that, as will now see, have not yet been adequately addressed in the dominant theologies of digital technologies.

\section{THEOLOGIES OF TECHNOLOGY}

\section{The Magisterium on Digital Technologies}

Since the Second Vatican Council approved Inter Mirifica, its Decree on the media of social communications in late 1963, the Magisterium has returned both regularly and occasionally to the sphere of what have become almost exclusively digital (rather than earlier analogue) technologies. Communio et Progressio, the fruit of the Council's call for further reflection, was published as a Pastoral Instruction in 1971 and is much more developed than the brief initial foray from the Council. On the twentieth anniversary of Communio et Progressio the Pontifical Council for Social Comunications delivered Aestatis Novae (February 1992) and very shortly before he died, John Paul II published his Apostolic Letter, The Rapid Development (January 2005). Running parallel have been the Popes' annual messages to the World Communications Day, itself an outcome of Inter Mirifica. We consider here the Decree, Pastoral Instructions, and Apostolic Letter then, given the greater immediacy in a rapidly developing digital culture, we focus attention upon the last ten years' annual messages.

In what will become a recurring refrain, Inter Mirifica establishes the media of social communications (its preferred designation over what otherwise is too loosely the "mass

\footnotetext{
${ }^{17}$ Jim Taylor, "Disconnectivity Anxiety", Huffington Post http://www.huffingtonpost.com/dr-jimtaylor/disconnectivity-anxiety_b_647773.html (accessed May 6, 2014).

${ }^{18}$ Florman, in his study of engineers, found traces of a "yearning for immensity" and concluded that "every manmade structure, no matter how mundane, has a little bit of cathedral in it, since man cannot help but transcend himself as soon as he begins to design and construct" S. Florman, The Existential Pleasures of Engineering - Second Edition (New York: St Martin's, 1994 [1976]), 126.

${ }^{19}$ Tine Kleif and Wendy Faulkner, '"I'm No Athlete [but] I Can Make This Thing Dance!" Men's Pleasures in Technology,' Science, Technology, \& Human Values 28: 2 (2003): 309. Kleif and Faulkner are quoting Judith S. McIlwee and J. Gregg Robinson, Women in Engineering: Gender, Power, and Workplace Culture (Albany: State University of New York Press, 1992), 139.

${ }^{20}$ Florman, The Existential Pleasures of Engineering - Second Edition, 128.

21 "personal computers get taken up in ways that signal the development of something beyond the practical and utilitarian. People buy an "instrumental computer," but they come to live with an intimate machine." Sherry Turkle, The Second Self: Computers and the Human Spirit. Twentieth Anniversay Edition (Cambridge, MA: MIT Press, 2005 [1984]), 173.

${ }^{22}$ Kleif and Faulkner, 'I'm No Athlete.'
} 
media") as a gift of God; a dimension of what talented people "have made with God's help."23 Both entertainment and instruction made possible through these media contribute to the development of societies and offer opportunities for spreading the Gospel. Recognizing that great harm can also ensue, the Council calls for a proper use that takes moral responsibility for systems that shape people's thinking - especially when those people can be unprepared for its effect upon them. The "right to information" demands high standards of professionalism on the part of not only journalists but artists in all genres as well as producers and retailers, in order that people can make properly-informed critical judgements on the matters of their day. The backdrop of the Cold War means it is no surprise that the Decree places great significance on the freedom of the press.

As its title states, the "unity and advancement" of people as social agents ought to be, for Communio et Progressio, the telos of technologies of communication. ${ }^{24}$ Through having a share in God's creative power, people are to work in cooperation towards furthering the common good of their life together; technologies are integral to sharing knowledge and enabling people to work together as they become more aware of others' lives, needs and aspirations. Naturally, this Pastoral Instruction is well aware that these technologies permit the flourishing of discord. Central to the theology of social communications is the "giving of the self in love"; counterposed to mere expressing ideas and emotion ${ }^{25}$ Christ was the Perfect Communicator and continues to enfold people in the communion he offers in the Eucharist. "Mutual understanding and shared ambition" are to thus configure the proper development and use of technologies for widespread, if not always mass, communication. ${ }^{26}$

Communio et Progressio recognizes the commercial pressures to capture an audience that must be resisted lest there be a downward spiral of appealing to the baser of human instincts (which could be best expressed as titillation, fantasy, voyeurism and schadenfreude). The Instruction asks the prescient question, "how can one be certain that the incessant appeal to emotion does not sap reason?". ${ }^{27}$ The potential effects on public opinion are of similar concern, especially for pluralist societies that might give uncritical priority to the majority opinion which, "is not necessarily the best or the closest to the truth." 28 In the late 1960 s we had not yet seen much infotainment so Communio et Progressio deals with news and entertainment in separate sections - although there is a prescience around commercial impetuses that had begun to move in disturbing directions. Pressures from advertisers do not escape the challenge of the Instruction: "unremitting pressure to buy articles of luxury can arouse false wants that hurt both individuals and families by making them ignore what they really need." ${ }^{29}$ The extensive discussion of the role of Catholics in the media and its use in spreading and supporting the Gospel is not germane to our immediate discussion.

Twenty years later, Aetatis Novae updates the same core moral principles for societies steeped even more deeply in "media culture" although not yet caught up in the explosion of digital technologies. Nevertheless, the construction of reality takes centre stage in moral and theological concern: "reality, for many, is what the media recognize as real; what media do not acknowledge seems of little importance." ${ }^{30}$ The privatization of broadcasting is seen as a retreat from a public service obligation, especially when media from one culture spread into others. Whilst a critical tone is present in earlier documents, Aetatis Novae is particularly exercised by the challenges of mass media that "exacerbate individual

\footnotetext{
${ }^{23}$ Second Vatican Council, Decree on the Media of Social Communications - Inter Mirifica (1963)., sec 1.

${ }^{24}$ Second Vatican Council, Pastoral Instruction on the Means of Social Communcation - Communion Et Progressio (1971)., sec 1.

${ }^{25}$ Communio Et Progressio, sec 11.

${ }^{26}$ Communio Et Progressio, sec 12.

${ }^{27}$ Communio Et Progressio, sec 21.

${ }^{28}$ Communio Et Progressio, sec 31.

${ }^{29}$ Communio Et Progressio, sec 60.

${ }^{30}$ Pontifical Commission for Social Communication, Pastoral Instruction on Social Communications Aetatis Novae (1992), sec 4.
} 
and social problems." 31 The injustices of a "digital divide" (although not yet termed as such) are coming into focus as is the domination of the media by elites. The fundamental interest of the common good is perceived to be side-lined by commercial priorities.

In The Rapid Development, the Word made flesh remains, as we would expect, that paradigmatic communication against which all human attempts at social interaction are measured and is also the incentive and redemptive possibility for communication with God and with other people. ${ }^{32}$ John Paul II here gives particular attention to the spread of the Gospel through new media including not only direct proclamation and education but through the manner in which Christian people communicate. The power of all media is such that both individuals' ethical formation and laws and codes are required to ensure that, as far as possible, these forms of communication contribute to furthering the common good, most specifically "safeguarding the centrality and dignity of the person, the primacy of the family as the basic unit of society and the proper relationship among them." ${ }^{33}$ The linked practices of formation, participation and dialogue need to be nurtured in order to sustain communication as a moral act. Jesus' warning of judgement upon our words (Matt. 12:35-37) is used by John Paul II to emphasise the jeopardy.

In the Papal Messages to the World Communications Days the broader theological themes surface in more precise application to distinct, but inter-related, topics. In general terms, the media (here traditional as well as digital) is a "familiar guest in many homes and families." ${ }^{34}$ It offers "exceptional opportunities for enriching the lives not only of individuals, but also of families," in terms of "information, education, cultural expansion, and even spiritual growth." ${ }^{35}$ Such appreciative observations are not without reservations for digital media rivals school, Church and "maybe even the home" as a source of influence. ${ }^{36}$ Whilst "words have an extraordinary power" so do images, particularly because the latter leave "lasting impressions" that shape attitudes. ${ }^{37}$ To a considerable extent, digital media are constructing reality for some people. ${ }^{38}$

As we have seen, the Popes have sought to affirm digital communications, not least because of the right to information. ${ }^{39}$ More specifically, digital media "help us feel closer to one another" so contribute to a sense of unity that may inspire solidarity and thus a more dignified life. ${ }^{40}$ The opportunity for listening and dialoguing is important in helping to break down walls. With its "immense possibilities for encounter and solidarity", the Internet "is something truly good, a gift from God." ${ }^{41}$ Benedict XVI felt able to talk about the creation of "a new 'agora'...in which people share ideas, information and opinions" not as ends in themselves, but rather for the communities that come into being. ${ }^{42}$ Believers have "opportunities for prayer, meditation and sharing the word of God" but the spirit in which

\footnotetext{
${ }^{31}$ Aetatis Novae, sec 13.

${ }^{32}$ John Paul II, Apostolic Letter - the Rapid Development (2005), secs 4 \& 5.

${ }^{33}$ The Rapid Development, sec 10.

${ }^{34}$ John Paul II, Message for the 38th World Communications Day: The Media and the Family - a Risk of Richness - May 23, 2004.

${ }^{35}$ John Paul II, The Media and the Family.

${ }^{36}$ Benedict XVI, Message for the 41st World Communicataions Day: Children and the Media - $a$ Challenge for Education - May 20, 2007. Here following Aetatis Novae, sec 4.

${ }^{37}$ John Paul II, Message for the 39th World Communications Day: The Communications Media - at the Service of Understanding among Peoples - May 8, 2005.

${ }^{38}$ Benedict XVI, Children and the Media; Benedict XVI, Message for the 42nd World

Communications Day: The Media - at the Crossroads between Self-Promotion and Service. Searching for the Truth in Order to Share It with Others - May 4, 2008.

${ }^{39}$ Inter Mirifica, sec 5.

${ }^{40}$ Francis, Message for the 48th World Communications Day: Communication at the Service of an Authentic Culture of Encounter - June 1, 2014.

${ }^{41}$ Francis, Communication.

${ }^{42}$ Benedict XVI, Message for the 47th World Communications Day: Social Networks - Portals of Truth and Faith; New Spaces for Evangelization - May 12, 2013.
} 
these actions are conducted is vital: "authenticity" is vital for it points to Christ, "the profound source of their hope and joy."

The burgeoning of digital social networks is evidence of the fundamental "human desire for relationship, communion and meaning." ${ }^{44}$ Such reaching out to others arises from the imprint of the image and likeness of God, "the God of communication and communion.", Whilst Benedict is well aware of the "ambiguity of progress", digital communications are "instruments are the service of a world of greater justice and solidarity." 46

The distortions caused by, or at least perpetuated by, digital communications are of particular concern in the papal messages - especially where these concern life, religion, morality or the family. ${ }^{47}$ Inter Mirifica, as we noted, had recognized that many people can find themselves unprepared for the influence of the media about their thinking. ${ }^{48}$ Benedict warns that distorted models of life are being imposed in some corners of the digital world, ${ }^{49}$ sometimes through the weight of too much information but also via content that is partial or provisional truth. ${ }^{50}$ The homogenizing of culture that is presented in the monoculture of much digital media stifles, argues Benedict, creative genius, and the subtlety of complex thought. This has negative consequences for "the specificity of cultural practices and the particularity of religious belief." 51

Commercial competitiveness contributes to lowering of standards and the problem of so-called "entertainment" trivializing violence. ${ }^{52}$ Economic materialism and ethical relativism are distortions that owe their promulgation to an "agenda dictated by dominant interests of the day. ${ }^{, 53}$ People are wrongly encouraged to indiscriminate "self-promotion" at the same time as their conscience is being manipulated ${ }^{54} \mathrm{In}$ an astute observation that has relevance far beyond only the concerns of the church but touches upon democratic processes, Benedict recognizes how "truth" is given worth in terms of popularity. ${ }^{55}$

There has been, so argues Benedict, a fundamental shift in patterns of communication and human relationships. ${ }^{56}$ So it is important to remember that communication is a human, not a technological achievement. ${ }^{57}$ Communication is integral to friendship, to respect and to dialogue and it is to the service of these high callings that the media is to be subject. ${ }^{58}$ With this in view, believers and people of good will are encouraged to remember that the digital world is not a parallel or purely virtual world. ${ }^{59}$ Benedict is asserting the continuity of

\footnotetext{
${ }^{43}$ Benedict XVI, Social Networks.

${ }^{44}$ Benedict XVI, Message for the 45th World Communications Day: Trust, Proclamation and Authenticity in the Digital Age - June 5, 2011.

${ }^{45}$ Benedict XVI, Message for the 43rd World Commnications Day: New Technologies, New Relationships. Promoting a Culture of Respect, Dialogue and Friendship - May 24, 2009.

${ }^{46}$ Benedict XVI, The Media - at the Crossroads.

${ }^{47}$ John Paul II, The Media and the Family

${ }^{48}$ Inter Mirifica, sec 4.

${ }^{49}$ Benedict XVI, The Media - at the Crossroads.

${ }^{50}$ Benedict XVI, Message for the 40th World Communications Day: The Media - a Network for Communication, Communion and Cooperation - May 28, 2006.\#40. The forum of questions and answers is not helped by a "surcharge of stimuli and data," Benedict XVI, Message for the 46th World Communications Day: Silence and Word - Path of Evangelization - May 20, 2012.

${ }^{51}$ Benedict XVI, The Media - a Network.

${ }^{52}$ Benedict XVI, Children and the Media. Here Benedict draws on Jesus' condemnation of those who harm children and the well-known metaphor of millstones around the drowning perpetrator's neck.

${ }^{53}$ Benedict XVI, The Media - at the Crossroads.

${ }^{54}$ Benedict XVI, The Media - at the Crossroads.

${ }^{55}$ Benedict XVI, Trust, Proclamation and Authenticity.

${ }^{56}$ Benedict XVI, New Technologies, New Relationships. Benedict XVI, Trust, Proclamation and Authenticity.

${ }^{57}$ Francis, Communication.

${ }^{58}$ Benedict XVI, New Technologies, New Relationships. Benedict XVI, Message for the 44th World Communicataions Day: The Priest and Pastoral Ministry in a Digital World - New Media at the Service of the Word - May 16, 2010.

${ }^{59}$ Benedict XVI, Social Networks.
} 
virtuous behavior and character that ought to be expected by people as they live in both digital and analogue worlds. Whatever "realities" might be digitally constructed the key component is always direct human relations. ${ }^{60}$ Christians' presence on the cyberspace highways is important and is to be guided by "concrete present and engaging" love for all. ${ }^{61}$ Here, as elsewhere, Christians are called to exercise a "diaconia of culture." ${ }^{62}$ This requires not only authenticity but a discipline of silence that resists perpetual and premature chatter, particularly developing the capacity to listen as a form of respectful evangelization. ${ }^{63}$ It is this, in many ways counter-cultural, approach to digital media that Francis picks up in his first such message: "those who communicate, in effect, become neighbours." 64

The ethical injunctions and guidance from the Magisterium are welcome in their affirmation of digital communications technologies whilst being alert to the great potential for harmful distortions - of news, information, and attitudes to violence. All these bear upon the dignity of human persons that properly requires to be defended. However, the communicator and the person communicated to, be she Christian or not, is assumed to be rather more free to critically engage with technology than is perhaps really the case. The paradigm of Divine communication has, in this respect, its limits. The capacity of God to communicate with human persons, when used analogously tends to diminish the hurdles of social communication. It is not merely that the hurdles are higher but that people are disabled by the technological paradigm or culture and so are hindered in both overcoming the hurdles and, more profoundly, being aware that they are even in a race. Odorless noxious fumes are acutely dangerous not only because we are unaware of being slowly poisoned but the fumes alter our cognitive capacity to realize what is happening to us even once some side-effects become apparent. It is this dimension that appears more prominently when we consider broader theologies of technology.

\section{Other Theologies of Technology}

Russian Orthodox theologian, Nicholas Berdyaev contends in the 1930s that inventions bear witness to man's creativeness therefore are good and valuable but whilst testifying to man's strength and power over nature thereby liberating man, these inventions also weaken and enslave in their mechanisation of human life. ${ }^{65}$ The desire for power, puts technology as a power over the self wherein we sacrifice our humanity for the sake of power for, as Bedyaev argues, "the will to justice is overcome by the will to power." ${ }^{\text {"66 }}$ As a result, people are being dehumanized by machines. ${ }^{67}$ "Technical

civilization," says Berdyaev, turns us into machines as it "demands that man shall fulfill one or other of his functions, but it does not want to reckon with man himself - it knows only his functions." ${ }^{68}$ Technology and capitalism have enslaved through "the dictatorship of money."69

George Grant, a Christian philosopher in Canada active from the mid-1940s through the mid-1980s, is critical of the dream to be masters over the earth which is being attempted by bringing the sciences and the arts into a new unity. ${ }^{70} \mathrm{We}$ can see, he argues, the interweaving of political and social decisions with "the pursuit and realization of

\footnotetext{
${ }^{60}$ Benedict XVI, Trust, Proclamation and Authenticity.

${ }^{61}$ Benedict XVI, The Priest and Pastoral Ministry in a Digital World.

${ }^{62}$ Benedict XVI, The Priest and Pastoral Ministry in a Digital World. Benedict here draws an analogy with the Court of the Gentiles, "a space...for those who have not yet come to know God."

${ }^{63}$ Benedict XVI, Silence and Word.

${ }^{64}$ Francis, Communication.

${ }^{65}$ Nicholas Berdyaev, The Destiny of Man (London: Geoffrey Bles: The Centenary Press, 1937), 2856.

${ }^{66}$ Nicholas Berdyaev, The Fate of Man in the Modern World (London: SCM Press, 1935), 30.

${ }^{67}$ Berdyaev, The Fate, 26.

${ }^{68}$ Berdyaev, The Fate, 33.

${ }^{69}$ Berdyaev, The Fate, 111.

${ }^{70}$ George Grant, 'Thinking About Technology,' Technology and Justice (Toronto: House of Anansi, 1986), 12.
} 
technological ends." ${ }^{, 71}$ We want to make our own future but, says Grant, that vision is itself bound up within a technological mindset: "we apprehend our destiny by forms of thought which are themselves the very core of that destiny.",72

It is French sociologist and Protestant theologian, Jacques Ellul who has championed the criticism of the technological dream of every more efficient production (and, consequently, life). Using his now famous notion of La technique Ellul gives an account of the automatism of technical choice. ${ }^{73}$ Technology is self-augmenting, "progressing almost without decisive intervention by man." ${ }^{, 74}$ One disastrous consequence occurs in the morality of technology: "technique never observes the distinction between moral and immoral use. It tends, on the contrary, to create a completely independent technical morality". ${ }^{75}$ Implementing technology in striving for efficiency can result in bad effects (such as industrial accidents or deliberate disregard for the safety of people and the natural environment); the tragedy is compounded by the use of more technology to address the negative outcomes. ${ }^{76}$

Efficiency demands that people are turned into means to an end; we are, claims Paul Tillich, "becoming tool[s] for the production of tools." contends, "the person is the end that cannot become means without being destroyed" and this is true also of the kingdom of God: "the meaning of...the kingdom of God is not the unity of things or their functions, but it is the unity of persons, including their relationship to the whole nonpersonal realm." ${ }^{, 78}$ In what Catholic philosopher and playwright, Gabriel Marcel terms "desacralization," technology strips life of its sacred attributes. ${ }^{79}$

Such criticisms are bad enough but Martin Heidegger argues that our capacity to interpret technology is itself profoundly compromised. Humanity stands within a technological enframing and the capacity to question technology is profoundly hindered because man is part of, and sees from the standpoint, of the technological. The only possibility is that art, specifically our reflection upon art, might enable us to question technology. ${ }^{80}$

Following in the footsteps of Heidegger and Ellul, Protestant philosopher of technology, Albert Borgmann, finds technology to be disburdening or unencumbering people

\footnotetext{
${ }^{71}$ Grant, 'Thinking About Technology,' 15.

72 Grant, 'Thinking About Technology,' 32. On the other hand, the Jesuit philosopher, W. Norris Clarke offers something of a corrective to wholly negative interpretations of our dream for control. Clarke draws on the Greek Fathers' recapitulation theology (particularly of Gregory of Nyssa and Maximus the Confessor) to present "man as the mediator between the material world and God, with the role of extending the work of redemption by mastering and ruling the material forces of the earth, so as to offer the whole creation back to God in a great 'cosmic liturgy"' W. Norris Clarke, 'Technology and Man: A Christian View,' in Carl Mitcham and Robert Mackey (eds), Philosophy and Technology: Readings in the Philosophical Problems of Technology (New York: The Free Press, 1972), 253. ${ }^{73}$ Jacques Ellul, The Technological Society, trans. John Wilkinson (London: Jonathan Cape, 1965), 7980.

${ }^{74}$ Ellul, The Technological Society, 85.

${ }^{75}$ Ellul, The Technological Society, 97.

${ }^{76}$ Grant, 'Thinking About Technology,' 16.

${ }^{77}$ Paul Tillich, The Spiritual Situation in Our Technical Society, ed. J. Mark Thomas (Macon, GA: Mercer University Press, 1988), 134.

${ }^{78}$ Tillich, The Spiritual Situation in Our Technical Society, 134.

${ }^{79}$ Gabriel Marcel, 'The Sacred in the Technological Age,' Theology Today 19 (1962): 35-36.

${ }^{80}$ This deeply negative, even despairing, understanding of technology lacks sufficient attention to how particular technologies are developed. Andrew Feenberg points out that Heidegger disregards the moment in the technical design process when someone might break with technological thinking, (Andrew T. Feenberg, 'Critical Evaluation of Heidegger and Borgmann,' in Robert C. Scharff and Val Dusek (eds), Philosophy of Technology : The Technological Condition : An Anthology (Malden, MA ; Oxford: Blackwell, 2003), 328.) Furthermore, the high level of abstraction that Heidegger deploys results in him failing to recognize difference in (i.e. within) the technical sphere, Feenberg, 'Critical Evaluation,' 330. Feenberg instead claims that the "real struggle is not between the complete and lowtech alternatives but with the realm of possibilities opened by the computer itself" Feenberg, 'Critical Evaluation,' 331.
} 
from the trials and tasks of life; tasks that hitherto deepened our appreciation of life because these involved effort and connection with nature and, often direct human interaction. Devices, in Borgmann's framework, make commodities such as warmth, transportation or food, etc., available with few demands upon us with the effect that "our once profound and manifold engagement with the world is reduced to narrow points of contact in labour and consumption." ${ }^{\prime 81}$ Our experience of the world's contingency is, argues Borgmann, reduced by technologies. He does not contend that, for example, the protection brought about by vaccines is morally regrettable. Nevertheless, he believes that such disengagement "greatly complicates the task of recovering a region of contingency and habitual grace." $\$ 2$

There is, however, a counter discourse that attends to the liberating and creative dimensions of technology. Alongside desires for efficient exploitation of resources, technology bears much of the weight of our dreams for liberation. It cannot be denied that life in a pre-technological world was harsh. Technological developments have liberated many (although not all) from "servitude to matter" and, now, argues Clarke, the liberated spirit of man turns back to the material world, to dominate in a new (active) way; for creative selfexpression and self-realisation. ${ }^{83}$ The use of man's new found power ought to be according to the proper ordering of values, in other words for the expression and fulfilment of man's higher and more spiritual capacities. ${ }^{84}$ Technology is to serve the light of the spirit with selfdenial as a moderating influence. However, Clarke mistakenly views technology as "morally neutral instruments. $" \$ 5$

Whereas technology has the dual potential to liberate and demonise, the blame is placed by Tillich at misuses by capitalism. ${ }^{86} \mathrm{He}$ places technology in the eschatological hope of the unity of humanity through its possibilities of liberation from the bounds of space and time. ${ }^{87}$ In somewhat similar vein, Pierre Teilhard de Chardin famously contends that technology offers liberation from our detachment from one another. ${ }^{88}$ The evolution of human consciousness is continuing, and into maximum complexity. Despite our warring, and as a consequence of our attempts to detach ourselves, we are, says Teilhard, mingled more and more together. "Planetized humanity" is his belief in the total reflexion of the planet upon itself which in, something akin to telepathy, there is direct psychic convergence of members. This leads to a domain of supervision and ideas, the noossphere; a whole greater than the sum of its parts in which everything (from rocks to people) takes on holistic importance.

Against liberation from bodies and materiality (as is envisioned by much cyborg writing), practical theologian Elaine Graham posits "the fabricated, technologized worlds of human labour and artifice as equally capable of revealing the sacred as is the innocence of 'nature'." ${ }^{89}$ Graham's Christian feminist concern for embodiment is not at the expense of technological developments for she recognises bodily augmentation (sometimes for the restoration of capacities lost through disease or injury). ${ }^{90}$

\footnotetext{
${ }^{81}$ Albert Borgmann, Technology and the Character of Contemporary Life : A Philosophical Inquiry (Chicago ; London: University of Chicago Press, 1984), 77.

${ }^{82}$ Albert Borgmann, Power Failure: Christianity in the Culture of Technology (Grand Rapids, MI: Brazos Press, 2003), 75.

${ }^{83}$ Clarke, 'Technology and Man: A Christian View,' 249.

${ }^{84}$ Clarke, 'Technology and Man: A Christian View,' 249.

${ }^{85}$ Clarke, 'Technology and Man: A Christian View,' 251.

${ }^{86}$ Tillich, The Spiritual Situation in Our Technical Society, 59.

${ }^{87}$ Tillich, The Spiritual Situation in Our Technical Society, 60.

${ }^{88}$ Pierre Teilhard de Chardin, The Future of Man, trans. Norman Denny (London: Collins, 1964).

${ }^{89}$ Elaine L. Graham, Representations of the Post/Human: Monsters, Aliens and Others in Popular Culture (Manchester: Manchester University Press, 2002), 233.

${ }^{90}$ With a feminist perspective that is similarly attentive to the social construction of technology, Rita Lester sees the importance of gender in "the production, distribution and use of technologies," Rita Lester, 'Ecofeminism and the Cyborg,' Feminist Theology 19 (1998): 29. Also on gender power relations on design and innovation, see Judy Wajcman, Technofeminism (Cambridge: Polity Press, 2004).
} 
Technology also carries within it our dreams of creativity. Berdyaev writes of an "ethic of creativeness" which is our response to the call of God to deploy the joint gifts of intelligence and the materials available in the world. ${ }^{91}$ Lutheran systematic theologian, Philip Hefner, draws on the idea of the human as "the created co-creator" in his discussions of technological achievements. ${ }^{92}$ In this respect, it is vitally important to recognize the social systems within which such creativity (including digital media) is exercised. Physicisttheologian, Ian Barbour's contextual interaction of science, society and technology makes this point well. ${ }^{93}$

Creativity may often be exercised in the teeth of resistance to any challenge to models of technological efficiency although, as Ellul expresses in his theological work, The Meaning of the City, the situation, in Christ, is not without hope: "God, by his act in Jesus Christ, made the city into a neutral world where man can be free again, a world where man finds possibilities for action." 94 Creativity is not, then, merely a case of technological inventiveness but is closely linked to a spirit of Christian mortification that resists "mere gratification of man's inferior appetites." 95 This approach demands that the technologist "transcends the obsession of number" ${ }^{96}$ and recovers a quality of inwardness that, important for Marcel, is inter-subjectivity. ${ }^{97}$

\section{Theologies of Technology for Digital Cultures of Blurred Boundaries}

Theologies of technology always respond to specific contexts. Without suggesting that the digital contexts of the early $21^{\text {st }}$ century are wholly discontinuous with those that have come before there are, at the very least, some different emphases. The pessimistic theologies of technology quite naturally reflect concerns over the automation of industrial manufacturing processes, much of which was enveloped by militaristic ambition, that brought economic and social consequences in the early $20^{\text {th }}$ century with the loss, in Europe and North America, of many opportunities for low-skill employment. Detrimental effects on the environment through pollution were poorly publicised although devastating for the lives of those affected. Technologies in the home, not least the washing machine, changed the possibilities for women which conservatives perceived to be a fracturing of "family life." Hanging over everyone's head from 1945 was the threat of nuclear and biological warfare; the catastrophic potential of technological achievements.

To view digital technologies as truly a gift from God requires a nuanced appreciation of what is a quite ambiguous "gift". First and foremost, we must not mistakenly conceive of those gifts as tools. What God has gifted, through the creative genius of humanity, also shapes its recipients. The depth of such formation is not consistent across all the various contexts in which different devices are used. Nevertheless, Heidegger's critique warns us that our very thinking about technologies is undertaken within a technological paradigm. We may have so internalized technological values and perspectives that these have become our worldview, the same worldview by which we seek to critically engage with and evaluate digital cultures. The Magisterial theology of digital technology gives insufficient weight to this conundrum. The very people whose unity and advancement might be engendered through digital technologies are men and women who are not merely immersed in technological culture but are saturated by it. The communicating "self given in love" is not a person who can be abstracted from the mental, social, political and spiritual shaping by the paradigm of digital technologies. At the

\footnotetext{
${ }^{91}$ Berdyaev, The Destiny, 164.

${ }^{92}$ Philip Hefner, The Human Factor: Evolution, Culture, and Religion (Minneapolis: Fortress Press, 1993), 270.

${ }^{93}$ Ian G. Barbour, Ethics in an Age of Technology: The Gifford Lectures 1989-1991. Vol. 2 (London: SCM Press, 1992), 20.

${ }^{94}$ Jacques Ellul, The Meaning of the City (Eugene, OR: Wipf \& Stock, 2003 [1970]), 170.

${ }^{95}$ Clarke, 'Technology and Man: A Christian View,' 252.

${ }^{96}$ Marcel, 'The Sacred,' 38.

${ }^{97}$ Marcel, 'The Sacred,' 38.
} 
same time, we ought not lose sight of the residual capacity of digitally-shaped people to reflect upon their being shaped. We are, for the meantime, far from being automatons.

As much as the Magisterium grapples with the effects of digital technologies upon social and economic life, the teaching conveys the impression of a world in which many boundaries remain intact. It is all well and good to talk about work, family, home, politics, and entertainment, and recognize that these are impacted by digital technologies for better and for worse. However, times have moved on and the blurring of the boundaries between these different domains demands additional theological perspectives. It is the contention of this paper that theologies of play offer a paradigm that facilitates our resistance to being subsumed by, and not just submerged in, digital cultures.

\section{PLAY}

When the boundaries between information and entertainment, work and leisure, and professional tools and toys are blurred, a turn to theologies of play holds potential for sharper insight. It is important to remember that in this paper we are not discussing technology that is presented as children's or adults' toys (e.g. toddler computer / video-gaming systems) although these are important. Our interest is in the "positioning strategies" that we adopt and are required of us as people who engage with digital technologies within the often ill-defined culture of infotainment, weisure and professional toys. ${ }^{98}$ Following a theory of the social construction, rather than any determinism, of technology we bring attention to the choices that people between technological options; options that depend on social interaction. ${ }^{99}$ Similarly, we are not reducing our positioning of technologies to toys and play and nothing more, but are recognizing this attitude, and form of engagement with our experience of technologies.

\section{Theories of play}

In the late Eighteenth Century Friedrich Schiller attempted an early formulation of play that relied on the correlation between the two instincts or impulsions he had theorized. The first he calls the sensuous, the other he names as the formal instinct. The sensuous instinct arises from our physical existence and thus encloses us in time. The formal instinct comes from our rational nature and, in its maintaining of our personality amidst all the changes we experience, sets us free from time. ${ }^{100}$ Furthermore, whilst the sensuous impulsion wants to be shaped by what it receives, the formal instinct is set towards self-determination; rather than receiving, the formal impulsion wishes to produce an object. ${ }^{101}$ These two instincts are correlated with neither dominating lest we lose our stability as a person. It is play that unites these drives, albeit paradoxically - inside and outside time, facilitating change and displaying identity, and exercising constraints whilst setting free. Schiller thus makes his famous dictum: "Man plays only when he is in the full sense of the word a man, and he is only wholly Man when he is playing." 102

Play as a basic category for all human studies was the approach taken by Johan Huizinga in Homo Ludens, first published in Switzerland in 1949. For Huizinga the "spirit of

\footnotetext{
${ }^{98}$ Elisabeth K. Kelan, 'Tools and Toys : Communicating Gendered Positions Towards Technology,' Information, Communication \& Society 10: 3 (2007).

${ }^{99}$ Donald MacKenzie and Judy Wajcman, 'Introduction: Technological Determinism and Reproduction,' in D. MacKenzie and J. Wajcman (eds), The Social Shaping of Technology (Buckingham: Open University Press, 1999).

${ }^{100}$ Friedrich Schiller, On the Aesthetic Education of Man in a Series of Letter, trans. Elizabeth Wilkinson and L.A. Willoughby (Bristol: Thoemmes Press, 1967). Letter XII

${ }^{101}$ Schiller, On the Aesthetic. Letter XIV

102 Schiller, On the Aesthetic, 80. Letter XV, emphasis original.
} 
playful competition" produced many fundamental forms of life with play serving as a metaphor for social meaning. ${ }^{103}$ Play is thus beyond the dichotomy of serious/not serious:

Summing up the formal characteristics of play we might call it a free activity standing quite consciously outside "ordinary" life as being "not serious," but at the same time absorbing the player intensely and utterly. It is an activity connected with no material interest, and no profit can be gained by it. It proceeds within its own proper boundaries of time and space according to fixed rules and in an orderly manner. ${ }^{104}$

Unsurprisingly, this definition is contested. Roger Callois, a French philosopher, found it simultaneously "too broad and too narrow" as well as missing the role of play in exposing mystery and secrecy. ${ }^{105}$ Huizinga's exclusion of material interest also, argues Callois, excludes betting, lotteries and the like. In differentiating games with respect to competition, chance, simulation and thrill-seeking Callois proffers a definition of play by which it is marked out as free, separate, uncertain, unproductive, governed by rules and make-believe. ${ }^{106}$

Play can be a means of handling trauma; a person has a compulsion to repeat symbolically experiences that were not sufficiently managed in the past. Some play might be an opportunity for catharsis in which pent-up or surplus emotions from the past are released. From a functional perspective, play can be preparation for the future; a person exercises new faculties. Erikson's focus is upon the toy world of childhood imagination: "to use objects endowed with special and symbolic meanings for the presentations of an imagined sense in a circumscribed sphere". ${ }^{107}$ In this ritualized procedure we dare a new chance that enables someone to alter both their thinking and their feeling about their past, present and future. Play is thus a "capacity for imagining different scenarios which may serve as make-believe in the search for a fitting vision and yet can take over to the point where the cognitive as well as the emotional quality of action is changed." ${ }^{108}$ Brian Sutton's claim for play is persuasive:

play is deceptive; it is a vehicle for antithetical purposes. It is the primitive communication system par excellence through which you can express and communicate all the longings, furtive wishes, glorious dreams, hopeless fears, that cannot be expressed in everyday arrangements...In play, more than anywhere else, apart from madness, the player can escape the usual orthodox links between signs and their referents. ${ }^{109}$

\section{Theologies of Play}

Christian traditions have been both wary of play and appreciative of its merits (within limits). Whilst recent explorations have wrestled with play's possibilities for reflecting God's nature and, in the face of political oppression, wresting a vision of hope in a different future, there is a tradition of a call to seriousness that sees a need for conversion from a life of play. St Chrysostom took the world to be a theatre, but not one in which we are to laugh but "to weep for our sins." ${ }^{110}$ Whilst some might sarcastically express their preference that God give them opportunities for laughing Chrysostom dispenses a rebuke: "It is not God who gives us the chance to play, but the devil." For Augustine, even eating is sinful if done in a spirit of pleasure; the only proper enjoyment is enjoyment of God. ${ }^{111}$ He seems to be caught up with how one can know one is eating only enough for sustenance and health rather than eating for

\footnotetext{
${ }^{103}$ Johan Huizinga, Homo Ludens: A Study of the Play Element in Culture (London: Routledge \& Kegan Paul, 1949), 173.

${ }^{104}$ Huizinga, Homo Ludens, 13.

${ }^{105}$ Roger Callois, in Play and Games) The Definition of Play (extract from Man (ed.), The Game Design Reader: A Rules of Play Anthology (Cambridge, MA: MIT Press, 2006 [1961]), 123-4.

${ }^{106}$ Callois, 128.

${ }^{107}$ Erik H. Erikson, Toys and Reasons: Stages in the Ritualization of Experience (London: Marion Boyars, 1978), 43.

${ }^{108}$ Erikson, Toys, 21.

${ }^{109}$ Sutton-Smith, Toys, 252-3.

${ }^{110}$ Chrysostom, Commentary on Matthew, Homily 6, 6; quoted in Hugo Rahner, Man at Play or Did You Ever Practise Eutrapelia? (London: Burns \& Oates, 1965), 98.

${ }^{111}$ Augustine Confessions X, 31
} 
enjoyment (which is closely associated with excess). Use of all good things, for example, music, apparel or utensils is to be both moderate and necessary. Sport, here coursing or watching a lizard, must lead to praise to God otherwise it is a diversion and thus a sin. In a similar vein the $16^{\text {th }}-17^{\text {th }}$ century Puritan William Law wrote of the "poorness of all worldly enjoyments" where he prefers to see pain and sickness as a greater call to God. Nevertheless, we may profit by the follies of the world as they may point, albeit inadvertently, to the greatness of religion and to the happiness of another life. ${ }^{112}$ Like Augustine, Law calls for "a religious exactness in the use of...innocent and lawful things." 113 The Reformer John Calvin, not generally ascribed with a cheery approach to life, offers a nuanced perspective on Augustinian severity. We are to use God's gifts to the end to which God created them. These have been created for our good, not our ruin. On food in particular "we shall find that [God] meant not only to provide for necessity but also for delight and good cheer." 114 Similarly respecting trees and fruit, their "beauty of appearance and pleasantness of odour" prevent both narrow-mindedness and immoderation.

By no means did Chrysostom's and Augustine's approach prevail to the exclusion of all others. Gregory of Nazianzus had made the audacious claim that "the Logos on high plays, stirring the whole cosmos back and forth as he wills, into shapes over every kind." 115 The $12^{\text {th }}$ century Saxon canon Hugh St Victor claimed that serious things taste better if spiced with kindly mockery. ${ }^{116}$ His near contemporary, John of Salisbury considered there to be something wrong with a po-faced person: "It is a pleasant thing and in no way contrary to a good man's honour that he should here and there unbend and be moved by seemly mirth."117 However, this strand was not ignorant of mirth's capacity to run away with itself; loss of control was inappropriate. As Hildebert of Le Mans counselled, "Permit thyself a few jests in the midst of thy serious work, but even they jesting should be carried out in a worthy manner." 118

Christian piety has been not a little eager in its disciplinary impetus to marshal the threat of idleness. The common phrase of recent years, "the devil finds work for idle hands" has evolved in variants but Isaac Watt's early $18^{\text {th }}$ century song for children captures the mood well: "In works of labour or of skill, / I would be busy too; / For Satan finds some mischief still / for idle hands to do." 119 To powerful rhetorical effect preachers such as John Wesley glorified work against the dangers of idleness and praised honest industry that generated income to be wisely, not frivolously spent:

despise delicacy and variety, and be content with what plain nature requires. Do not waste any part of so precious a talent merely in gratifying the desire of the eye by superfluous or expensive apparel, or by needless ornaments. Waste no part of it in curiously adorning your houses; in superfluous or expensive furniture; in costly pictures, painting, gilding, books; in elegant rather than useful gardens. ${ }^{120}$

Wesley's exhortation appeals to the dominical injunction to "let the dead bury their dead"; the disciples of the Lord are on a more urgent mission to which no restraining attachments are permissible.

Coming to more contemporary commentators, Robert Johnson has given particular attention to Genesis 1-11, the Sabbath ordnance and Wisdom Literature with respect to play. In finding every tree pleasant, vines producing wine that gladdens the heart and oil as a sign of gladness (Gen 2:9 and Ps 104), Johnson leaves behind a utilitarian approach to the natural

\footnotetext{
${ }^{112}$ William Law, Serious Call to Devout and Holy Life (1729). Chapter 13

${ }^{113}$ Law, Serious Call to Devout and Holy Life. Chapter 7

${ }^{114}$ John Calvin, Institutes of the Christian Religion, II.2

${ }^{115}$ Gregory of Nazianzus, Carmina I, 2, 2, vv. 589-90 quoted in Rahner, Man, 23.

${ }^{116}$ Rahner, Man, 36. Rahner here refers to a quotation in Curtius, Romanishe Forschungen, 53 (1939), 8.

${ }^{117}$ Polycraticus, I, 8; quoted in Rahner, Man, 37.

${ }^{118}$ Libellus de IV Virtutibus Vitae Honestae; quoted in Rahner, Man, 37.

${ }^{119}$ Isaac Watts, “Against Idleness and Mischief” Song 20, Divine and Moral Songs for Children, 1715.

${ }^{120}$ John Wesley, Sermon 50 (text from the 1872 edition) http://new.gbgmumc.org/umhistory/wesley/sermons/50/
} 
world. The Sabbath is a call to abstain from work, not as is often presented, a call to worship. Johnson sees the Sabbath as a parenthesis which had no outside design; an instance of play in which "its non-instrumentality proved productive." ${ }^{.21}$ Recognising life as a gift as well as a task the Sabbath-play has ethical significance in allowing servants and labourers to rest and be refreshed. The community is thus "freed for the Sabbath by the even of the Exodus." 122 In Ecclesiastes Johnson finds a God whose sovereignty frees people to enjoy, rather than having to attempt a futile control of, life. ${ }^{123}$ Play, he argues, is "preparatory to our experience of God" but one may also find joy in labour. ${ }^{12}$

For Hugo Rahner the creation of the world and of humanity is meaningful although not necessary. ${ }^{125}$ Drawing on Proverbs 8:22-31 he interprets Wisdom rejoicing before the LORD and Wisdom's delight in humanity in terms of play. ${ }^{126}$ Humanity is playing too, for people are both of heaven and earth. Play captures these dual, but not dichotomous, dimensions of being "grave-merry." 127 The church is playing for there is nothing of compulsion or calculation in the origin of the church. ${ }^{128}$ Ecclesia is the True Eve ${ }^{129}$ and liturgy is the divine game. ${ }^{130}$ This re-sets our perspective in a way that is not a denial of the world but a vital aspect of not being tied down by the world. Christians are able to serve the world more faithfully - although we must not mistake the productivity of such play by instrumentalizing it:

In play earthly realities become, of a sudden, things of the transient moment, presently left behind, then disposed of and buried in the past; the mind is prepared to accept the unimagined and incredible, to enter a world where different laws apply, to be relieved of all the weights that bear it down, to be free, kindly, unfettered and divine. ${ }^{131}$

Rahner attempts to respond to the reasonable criticism of Christians laughing when they ought to be weeping. He finds that the Christian adoption of the Greek serious-serene man to be standing between two extremes: the bomolochus who jokes at every turn to gain a meal or two, and the agroikos whose disposition was one of course stiffness. Eutrapelia is "play for the sake of seriousness". 132

For Rahner we play to reflect God's nature, for the sake of our good health, to raise our imagination above the mundane and to relativize any self-importance that is really a lack of faith in God's glory. Similarly, David Miller argues that we should see play in its breadth: "play is not only a dimension of knowing but also a dimension of living and feeling and willing, in short, a way of being." 133 Play has a crucial contribution to our envisaging our future as well as describing our present circumstances in terms other than within the constraints of language. ${ }^{134}$

Brazilian liberation theologian Rubem Alves has identified the political importance of play. Alves sees play as a way of subverting dominant values that are being imposed upon us. He finds Jesus refusing to play the game in not preserving the past in the present but opening the present to the future through becoming like little children (who play). Play is "nonproductive activity" and it delivers pleasure. ${ }^{135}$ Play subverts the idea that power is the answer

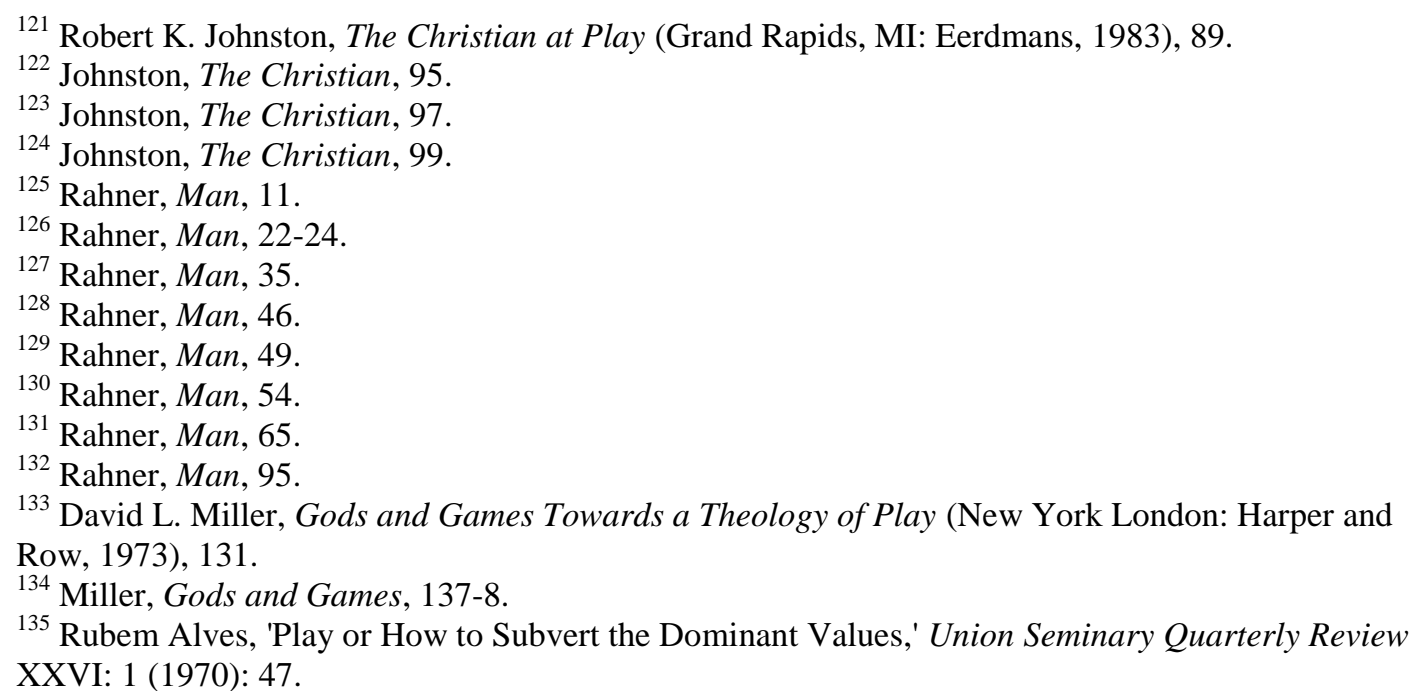


to overcoming others' power: "We are trapped not for lack of power, but by the unmatched effectiveness of our irrationality." ${ }^{136}$ By playing, with its consequence for roles, we are able to envisage ways of living together that embodies God's forgiveness. In this sense play is, for Alves, an aperitif reminding us that our destiny is not confined to this world:

by being the playing community, [the church] becomes the 'aperitif' offered to the world. After the world tastes it, its imagination is to run wild, free from the yoke of the logic of production and consumption which repressed it. Has not this liberation of imagination something to do with metanoia, repentance? ${ }^{137}$

Through play we resist control of our imagination, particularly when this is exercised for the commercial interests of the state. ${ }^{138}$ Play thus has ethical and prophetic significance for it makes "a radical denial of the logic of the adult world," 139 challenging it with a utopian element. In play we see with the heart. ${ }^{140}$ As Alves so vividly declares, "hope is hearing the melody of the future. Faith is to dance to it." ${ }^{\prime 11}$

With similar concerns to those of Alves, Jürgen Moltmann addresses the question of how Christians can be playing in the face of suffering across the world. His response is multi-faceted, with a liberation agenda that requires breaking play from the grip of ruling authorities. People's minds and bodies are kept captive by messages that current conditions are what they are so the "fetters of inevitability of that which is" need to be shaken off. ${ }^{142}$

Liberating play rests on God's creation of the world in order to enjoy it: "creation is a play of [God's] groundless and penetrating wisdom." ${ }^{143}$ This theme is carried over into Moltmann's interpretation of the eschatological question. Whilst it is tempting to think of the End as the completion of a project or the fulfilment of a goal this, according to Moltmann, a mistaken framing. To achieve a goal is indeed an end point - but therein lies the problem. Once achieved, the goal passes behind us and we are left with either purposelessness or, as we do in this life, seek other goals to work towards. If there is a final goal then it would be far better to keep seeking to reach it rather than to complete it. In eschatological terms, "the vision of heaven is horrifying for a life which is made meaningful only by a goal, because it offers something like eternal boredom." ${ }^{144}$ Instead of conceiving the eschatological hope in terms of a goal it needs to be viewed as purposeless, "as a song of praise out of unending joy, as a round dance filled with variations, as the consummated harmony of body and soul." So, liberation is from subjection to goals and achievements. ${ }^{146}$

\section{DIGITAL TECHNOLOGIES AND A THEOLOGY OF PLAY}

We are now in a position to present the benefits of including a lens of a theology of play for considering digital technologies. The tradition of a call to seriousness demands that we have second thoughts about the expenditure we make on our technological "toys." We have to take for granted the built-in obsolescence of many devices but we are left wondering

\footnotetext{
${ }^{136}$ Rubem Alves, Tomorrow's Child: Imagination, Creativity, and the Rebirth of Culture (New York: Harper \& Row, 1972), 6.

${ }^{137}$ Alves, 'Play,' 57.

${ }^{138}$ Alves, Tomorrow's Child, 26, 31.

139 Alves, Tomorrow's Child, 94.

${ }^{140}$ Alves, Tomorrow's Child, 124.

${ }^{141}$ Alves, Tomorrow's Child, 195. Emphasis in original.

142 Jürgen Moltmann, 'How Can I Play When I'm in a Strange Land? ,' The Critic 29: May/June (1971).

${ }^{143}$ Moltmann, 'How Can I Play,' 17.

${ }^{144}$ Moltmann, 'How Can I Play,' 19.

${ }^{145}$ Moltmann, 'How Can I Play,' 19.

${ }^{146}$ Robert Neale has reached somewhat different conclusions to Moltmann who exempts the crucifixion from the frame of play. Neale argues that play has to do with both God and death because it involves suspense, a vital element of play, and adventure in God himself: "religion is created by the adventures of mature human beings at play, And these adventures happen to us now because they first happened to God himself' Robert E. Neale, 'The Crucifixion as Play,' in Jürgen Moltmann (ed.), Theology of Play (New York: Harper \& Row, 1976), 80.
} 
just how excessive might be our personal financial investment. It is also true that many of our devices are used in multiple contexts (for work as well as pleasure) so it is difficult to make fair judgments about what we spend on them. We ought not, of course, lose sight that the information brought to us about these devices is itself often packaged as infotainment.

Questions of solidarity, that have featured prominently in magisterial teaching on social communications, also take a further turn when we think of "excess." Devices that enable - and perhaps encourage - solidarity across economic and international boundaries may be assembled in production plants that rely on a low-wage economy. Playing with, and through, technologies that are partly the result of other people's labour in less than dignified contexts has to give us pause for thought. Nero has traditionally been criticized for fiddling whilst Rome burned. It is not wholly hyperbolic to perhaps find ourselves guilty of clicking whilst communities of low-paid workers toil. This is not to negate claims and hopes for solidarity but a call to seriousness in the face of a culture of play and entertainment reminds us that solidarity is not universal and, even when it might occur, the already poorest workers may be paying a high price.

As we have seen, a gift of mirth can be counterpoised to seriousness. However, authenticity and integrity are practiced in digital cultures that give great prominence to satire, cynicism and, at worst, cyber-bullying by Internet trolls. Racist or misogynist "humour" appears to have no adverse effect on people who are neither racist nor misogynist. But, highly significantly, such "joking" appears to validate such attitudes in those already holding them, giving people a perceived "permission" to express what they might otherwise keep to themselves. ${ }^{147}$ Mirth is both a highly valuable dimension of human experience and fraught with issues of power. It is difficult enough in routine social encounters amongst friends to always be confident that joking and banter remain a positive experience for everyone in the group. Using humour to diminish another person, to get an advantage over them or to secure one's own position with a group is an everyday practice. In the rough and tumble of friendships such jostling for approval is grist to the mill and often distributed with an equity that is largely policed by the group. Given that the infotainment, weisure and professional toys consistently blur boundaries it is much harder to combine mutual protection and jesting.

By refusing to romanticize or idealize play we can have some hope that distinct boundaries might be recovered - even if the boundaries are flexible and gradients rather than sharp edges. The cruelty of school playgrounds, often continued around the water-cooler in office environments years later, is a salutary reminder of the power of play. It is little surprise that the degree of anonymity that online activities can appear to offer exacerbates the detrimental aspects of mirth. Once again, it is the blurring of boundaries between digital and non-digital worlds that means we have to be alert to the ways in which poisonous denigration of individuals and groups leaches from one dimension to the other. It is insufficient to relegate online abuse to a supposedly sequestered digital space from which victims can be told simply to avoid.

As we have seen, some theologies of play have been particularly concerned with idleness. In the world of weisure it has very from clear what being idle now means. Whilst it could be tempting to resort to the tradition of Sabbath, also a significant theme in theologies of play, it is once more the blurring of boundaries that makes this problematic. There might be circumstances in which Christians would attempt to decouple weisure into more rigidly distinct compartments of work and leisure. However the expectations (and veiled threats) of managers in a competitive employment market bear heavily upon many people - Christian worshippers included. Some are more discrete than others, but people checking work emails on a smartphone during Mass is not an uncommon practice. The dignity of the person is diminished when not even worship is a protected space. Whilst vociferous debates rage over the separation of church and state there is remarkably little defence of a separation between church and commerce.

\footnotetext{
${ }^{147}$ Thomas E. Ford and others, 'Sexist Humor and Beliefs That Justify Societal Sexism,' Current Research in Social Psychology 21: 7 (2013).
} 
The role of digital technologies in creative imagining is largely absent from current theologies of technology. At most we find an appreciation of the liberation from actions of brute existence that technologies have brought. This liberation is not generally extended to the mind and envisioning of the alternative futures. There are, extensive visions of digital futures featuring Artificial Intelligence and human-machine integration in cyborg bodies. However, the possibility of digital technologies enhancing our playful creative imagination is not a sufficiently overt theme in theological frameworks. We need to recover play within digital environments as well as deploying it as a theological critique. It is perhaps only through appreciating the gift of play more fully that we will be motivated to at least begin to reinstate the boundaries subsumed by weisure and infotainment. Here we would have a re-invigorated theological critique of the instrumentalization of play - and of human beings as a whole - in digital cultures. A divine call back to purposelessness would need to be differentiated from the despair of nihilism but would be a recovery of the playing-human.

Genuine play made possible within our properly purposeless life in Christ offers the critical traction denied to those enclosed within a technological paradigm. We may not be able, or indeed need, to fully reconstitute the boundaries of information, entertainment, work and leisure but playing, alone and with others, at least puts us in another mode of being for a time. Worship, if it too can be freed from its all too common framing as a task or duty, is another practice of the human-at-play.

There is, of course, a paradox in suggesting that play can be a critical tool towards digital technologies. Such a stance would seem to instrumentalize play once again and nullify its purposelessness. The paradox is only problematic if we set out to play with the goal of availing ourselves of its benefits. We can play simply for the sake of it - perhaps, we might say, even for God's sake - and yet benefit from play's by-products. God's playing, in its free, unconditioned, abandonment gives us a paradigm for our purposeless, yet useful, play. The universe that resulted from God's playing was not necessary - yet no less important for being so. The human at play benefits, not least through liberating her imagination - but does not play in order that she be liberated.

Our condition - shaped by digital technologies and shaping them - is too serious for us not to play. That play may be with or by means of digital technologies but it may also involve some divesting of devices for a time. Either way, we need God's gift of play in order to handle God's gift of digital technologies.

\section{References}

Alves, Rubem. "Play or How to Subvert the Dominant Values." Union Seminary Quarterly Review XXVI, no. 1 (1970): 43-57.

Tomorrow's Child: Imagination, Creativity, and the Rebirth of Culture. New York: Harper \& Row, 1972.

Barbour, Ian G. Ethics in an Age of Technology: The Gifford Lectures 1989-1991. Vol. 2. London: SCM Press, 1992.

Benedict XVI. Message for the 40th World Communications Day: The Media - a Network for Communication, Communion and Cooperation - May 28, 2006, 2006.

Message for the 41st World Communicataions Day: Children and the Media - a Challenge for Education - May 20, 2007, 2007.

Message for the 42nd World Communications Day: The Media - at the Crossroads between Self-Promotion and Service. Searching for the Truth in Order to Share It with Others - May 4, 2008, 2008. 
Message for the 43rd World Commnications Day: New Technologies, New Relationships. Promoting a Culture of Respect, Dialogue and Friendship - May 24, 2009, 2009.

Message for the 44th World Communicataions Day: The Priest and Pastoral Ministry in a Digital World - New Media at the Service of the Word - May 16, 2010, 2010.

. Message for the 45th World Communications Day: Trust, Proclamation and Authenticity in the Digital Age - June 5, 2011, 2011.

. Message for the 46th World Communications Day: Silence and Word - Path of Evangelization - May 20, 2012, 2012.

. Message for the 47th World Communications Day: Social Networks - Portals of Truth and Faith; New Spaces for Evangelization - May 12, 2013, 2013.

Berdyaev, Nicholas. The Fate of Man in the Modern World. London: SCM Press, 1935.

The Destiny of Man. London: Geoffrey Bles: The Centenary Press, 1937.

Borgmann, Albert. Technology and the Character of Contemporary Life : A Philosophical Inquiry. Chicago ; London: University of Chicago Press, 1984.

Power Failure: Christianity in the Culture of Technology. Grand Rapids, MI: Brazos Press, 2003.

Callois, Roger. In The Game Design Reader: A Rules of Play Anthology, ed. Play and Games) The Definition of Play (extract from Man, 123-28. Cambridge, MA: MIT Press, 2006 [1961].

Carter, Cynthia, and Stuart Allan. "'If It Bleeds, It Leads': Ethical Questions About Popular Journalism." In Ethics and Media Culture: Practices and Representations, ed. David Berry, 132-53. Burlington, MA and Abingdon: Focal Press, 2013 [2000].

Clarke, W. Norris. "Technology and Man: A Christian View." In Philosophy and Technology: Readings in the Philosophical Problems of Technology, ed. Carl Mitcham and Robert Mackey, 247-58. New York: The Free Press, 1972.

Conley, Dalton. Elsewhere, USA. New York: Vintage Books, 2010.

Delli Carpini, Michael X., and Bruce A. Williams. "Let Us Infotain You: Politics in the New Media." In Mediated Politics: Communication in the Future of Democracy, ed. W. Lance Bennett and Robert M. Entman, 160-81. Cambridge: Cambridge University Press, 2001.

Ellul, Jacques. The Technological Society. Translated by John Wilkinson. London: Jonathan Cape, 1965. The Meaning of the City. Eugene, OR: Wipf \& Stock, 2003 [1970].

Erikson, Erik H. Toys and Reasons: Stages in the Ritualization of Experience. London: Marion Boyars, 1978. 
Feenberg, Andrew T. "Critical Evaluation of Heidegger and Borgmann." In Philosophy of Technology: The Technological Condition : An Anthology, ed. Robert C. Scharff and Val Dusek, 327-37. Malden, MA ; Oxford: Blackwell, 2003.

Fisher, Eran. Media and New Capitalism in the Digital Age: The Spirit of Networks. New York: Palgrave Macmillan, 2010.

Florman, S. The Existential Pleasures of Engineering - Second Edition. New York: St Martin's, 1994 [1976].

Ford, Thomas E., Julie A. Woodzicka, Shane R. Triplett, and Annie O. Kocherberger. "Sexist Humor and Beliefs That Justify Societal Sexism." Current Research in Social Psychology 21, no. 7 (2013): 64-81.

Francis. Message for the 48th World Communications Day: Communication at the Service of an Authentic Culture of Encounter - June 1, 2014, 2014.

Gordon, A. David, and John Michael Kitross. Controversies in Media Ethics - 2nd Edition. New York: Longman, 1999.

Graham, Elaine L. Representations of the Post/Human: Monsters, Aliens and Others in Popular Culture. Manchester: Manchester University Press, 2002.

Grant, George. "Thinking About Technology." In Technology and Justice, 11-34. Toronto: House of Anansi, 1986.

Hefner, Philip. The Human Factor: Evolution, Culture, and Religion. Minneapolis: Fortress Press, 1993.

Hinsliff, Gaby, "The Merge: How Our Work-Life Balance Is Changing", The Guardian http://www.theguardian.com/money/2013/jan/01/merge-work-life-balance (accessed May 6, 2014).

Huizinga, Johan. Homo Ludens: A Study of the Play Element in Culture. London: Routledge \& Kegan Paul, 1949.

Jebril, Nael, Erik Albæk, and Claes H. de Vreese. "Infotainment, Cynicism and Democracy: The Effects of Privatization Vs Personalization in the News." European Journal of Communication 28, no. 2 (2013): 105-21.

John Paul II. Message for the 38th World Communications Day: The Media and the Family a Risk of Richness - May 23, 2004, 2004.

Apostolic Letter - the Rapid Development, 2005.

. Message for the 39th World Communications Day: The Communications Media at the Service of Understanding among Peoples - May 8, 2005, 2005.

Johnston, Robert K. The Christian at Play. Grand Rapids, MI: Eerdmans, 1983.

Jurgenson, Nathan, "The IRL Fetish", The New Inquiry http://thenewinquiry.com/essays/theirl-fetish/ (accessed 2 May 2014).

Kelan, Elisabeth K. "Tools and Toys : Communicating Gendered Positions Towards Technology." Information, Communication \& Society 10, no. 3 (2007): 358 - 83. 
Kleif, Tine, and Wendy Faulkner. "'I'm No Athlete [but] I Can Make This Thing Dance!" Men's Pleasures in Technology." Science, Technology, \& Human Values 28, no. 2 (2003): 296-325.

Law, William. Serious Call to Devout and Holy Life, 1729.

Lester, Rita. "Ecofeminism and the Cyborg." Feminist Theology 19 (1998): 11-33.

MacKenzie, Donald, and Judy Wajcman. "Introduction: Technological Determinism and Reproduction." In The Social Shaping of Technology, ed. D. MacKenzie and J. Wajcman, 269-80. Buckingham: Open University Press, 1999.

Marcel, Gabriel. "The Sacred in the Technological Age." Theology Today 19 (1962): 27-38.

Mattheiß, Tamara, Carina Weinmann, Charlotte Löb, Katharina Rauhe, Katharina Bartsch, Franziska S. Roth, Sabine Spenkuch, and Peter Vorderer. "Political Learning through Entertainment - Only an Illusion? How Motivations for Watching TV Political Talk Shows Influence Viewers' Experiences." Journal of Media Psychology: Theories, Methods, and Applications 25, no. 4 (2013): 171-79.

McIlwee, Judith S., and J. Gregg Robinson. Women in Engineering: Gender, Power, and Workplace Culture. Albany: State University of New York Press, 1992.

Miller, David L. Gods and Games Towards a Theology of Play. New York London: Harper and Row, 1973.

Moltmann, Jürgen. "How Can I Play When I'm in a Strange Land?" The Critic 29, no. May/June (1971): 14-23.

Neale, Robert E. "The Crucifixion as Play." In Theology of Play, ed. Jürgen Moltmann, 7686. New York: Harper \& Row, 1976.

Pontifical Commission for Social Communication. Pastoral Instruction on Social Communications - Aetatis Novae, 1992.

Rahner, Hugo. Man at Play or Did You Ever Practise Eutrapelia? London: Burns \& Oates, 1965.

Schiller, Friedrich. On the Aesthetic Education of Man in a Series of Letter. Translated by Elizabeth Wilkinson and L.A. Willoughby. Bristol: Thoemmes Press, 1967.

Second Vatican Council. Decree on the Media of Social Communications - Inter Mirifica, 1963.

Pastoral Instruction on the Means of Social Communcation - Communion Et Progressio, 1971.

Sutton-Smith, Brian. Toys as Culture. New York: Gardner Press, 1986.

Taylor, Jim, "Disconnectivity Anxiety", Huffington Post http://www.huffingtonpost.com/drjim-taylor/disconnectivity-anxiety_b_647773.html (accessed May 6, 2014).

Teilhard de Chardin, Pierre. The Future of Man. Translated by Norman Denny. London: Collins, 1964. 
Tillich, Paul. The Spiritual Situation in Our Technical Society, ed. J. Mark Thomas. Macon, GA: Mercer University Press, 1988.

Turkle, Sherry. The Second Self: Computers and the Human Spirit. Twentieth Anniversay Edition. Cambridge, MA: MIT Press, 2005 [1984].

Wajcman, Judy. Technofeminism. Cambridge: Polity Press, 2004.

Winnicott, D.W. Playing and Reality. London: Tavistock Publications, 1971. 